\title{
The Ethics Of Crisis Management: A Juxtaposition Of Examples In Cognitive- Decision Making And Framing In Corporate Crisis Management
}

Thain Y. Hagan (E-mail: sampson@montana.com), University of Montana Shelby Jo Long (E-mail: umshelbyjo@ yahoo.com), University of Montana

\begin{abstract}
Ethical decision-making is a cognitive process that must be effectively managed within crisis situations that face corporations on a daily basis. Two juxtaposed cases are presented that help to define good decision-making in crisis management and bad decision-making. The two corporations used as case studies are Malden Mills and Enron.
\end{abstract}

\section{INTRODUCTION}

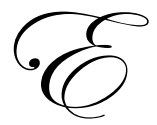

thical problems or synonymously, moral problems, arise each day during the course of a business day. The ramifications of how executives handle these situations as pertaining to the corporation and the stakeholders involved delineates how morally responsible the executive is to the corporation and to the stakeholders of the corporation. The executive employs a cognitive ethical decision-making process (CDM) (Street, Douglas, Geiger, \& Martinko, 2001) in order to identify the moral issue and thereby activates the processes of decision-making. From this point, the individual uses a framing process (Hallahan, 1999) in order to produce adequate communications that represent the best interests of the stakeholders and the corporation. Organizational crises are major ethical issues that the organization must overcome. Organizational crises must be successfully managed by executives to eliminate the escalation of the crisis, create a positive impact rather than a negative impact, and promote credibility of the corporation.

"Corporate crisis management is concerned with managing organizations in such a way that potential crises can be averted, and that damage from the actual crises can be minimized (Simola, 2003, p.351; Pearson, \& Clair, 1998). Issues in crisis management as argued by Pauchant and Mitroff (1992) are "fundamentally ethical" (Simola, 2003). Efficient organizational operation requires business policies, dimensions of human interaction and communication activities in an organizational setting to interact with intentions of achieving organizational goals (Cheney \& Christenson, 2000). During times of crisis, many facets work together to create an image of an efficient and stable organization including activities in public relations, issue management; marketing, identity, and crisis management. Executives attempt to unify the organization through these communicative methods to maintain employee and consumer confidence. "Crisis is part of the natural organizational process" and can confront the organization's ability to function, or be pivotal for organizational growth and change (Seeger, Sellnow, \& Ulmer, 1998, p.233). When organizations are forced to supervise unexpected situations, they must consider how all resources operate within efficient means. Each executive decision-maker in business must take into consideration the ethical ramifications of each crisis decision. These decisions become problematic because of the financial obligations each executive has to the corporation and the shareholders of that corporation. It is the purpose of this paper to present a juxtaposition of the ethics of cognitive decision-making (Street, et.al. 2001) in corporate crisis management through the presentation of two different cases, Malden Mills and Enron. 


\section{DEFINING ETHICAL BEHAVIOR}

Perceptions of ethical behavior are shaped and maintained by the leaders of organizations, which can be preserved as ethical or unethical in any given situation especially crisis situations (Simola, 2003; Sims \& Brinkman, 2002). The relationship between ethics and strategies for leadership in organizations involved in crisis situations should be considered central for dealing with crisis (Simola, 2003; Schwartz, 2000). The first step in the process of pinpointing ethics as the center point of crisis communication is to define moral or ethical behavior as it pertains to the cognitive-decision making process.

Morris (2004) defines a moral problem as, "a choice from among alternative courses of action, made unilaterally by an individual or group of individuals, where at least one of the proposed actions resulting from the decision involves modifying the life plan of another individual or group of individuals (p.353)." Using the following definition to guide our analysis of ethical problems associated with crisis management the two case studies presented allow us to delineate more thoroughly the proprieties and improprieties the ethical decisions made by the leader(s) of Malden Mills and Enron.

Using the Morris definition for defining a moral problem begs for the defining of the phrases moral problem and ethical decision-making. Research into a moral problem tries to extricate a definition by not using terms commonly associated with morality and ethics, such as, good and bad, right or wrong or duty (Morris, 2004). However, using a "morally neutral definition" (Morris, 2004, p.348) does not allow the decision to be judged as being morally acceptable in a societal reference. A moral problem must be deemed as good or bad, right or wrong, or dutiful as it pertains to the identity of the organization, the membership of the organization, and society.

Researchers approach the delineation of the properties of moral problems in a variety of ways, but each description contains many of the same references to what a moral problem is and how it must be treated within the organizational setting. Velasquez (1998) presents the decision-making process as a way of making judgments of rightness of wrongness, goodness or badness based on standards. Velasquez presents five criteria in order to identify a moral standard (Morris, 2004).

"(1) Moral standards deal with matters that we think can seriously injure or seriously benefit human beings. (2) Moral standards are not established or changed by the decisions of authoritative bodies. (3) We feel that moral standards should be preferred to other values (especially) self-interest. (4) Moral standards are based on impartial considerations. (5) Moral standards are associated with special emotions and a special vocabulary (Morris, 2004; Velasquez, 1998, p.10-11).”

DeGeorge (1999) identifies three characteristics involved with the descriptions of moral judgments and the actions involved with moral judgments (Morris, 2004).

"(1) Moral judgments about the rightness or wrongness of an action are held to be universally applicable. (2) Moral judgments are important that they override other considerations. (3) Moral praise can properly accompany the doing of morally right actions, and moral blame can properly accompany acting immorally (Morris, 2004, DeGeorge, 1999, p.37).”

Harris (2002) identifies four characteristics of moral problems (Morris, 2004).

"(1) Moral problems are resolved by the prescription of conduct. (2) Moral problems are resolved from an impersonal standpoint. (3) Moral problems regard serious issues. (4) Moral problems involve issues that can not be settled by appeal to facts, authority, tradition, or consensus (Morris, 2004; Harris, 2002, p.9-10)."

While the above-mentioned researchers approach moral problems using different language, the meanings associated to moral problems are relatively the same. Moral problems are serious and ethical in nature, moral 
problems are ambiguous and remain ambiguous until a decision is rendered that answers the moral dilemma, and resolution comes from an impersonal standpoint. Resolutions come in the form of ethical decisions.

Organizational leaders make ethical decisions based on the best interest of the corporation; however, for society these decisions may not be the best course of action. For this paper, ethical decisions will be those decisions that are both legal and morally acceptable to a larger community (Street, Robertson, \& Geiger, 1997; Jones, 1991) whether this community is the organization or society.

The environment in which the individual is socialized shapes their ethical decisions. Research has shown that individuals have different views concerning ethical behavioral intentions, and that each individual's own ethical intentions are influenced simultaneously by their ethical attitude, personal values, and perceived behavioral control, while their own ethical attitudes indirectly influence their personal values (Lin \& Ding, 2003). Leaders are influenced by personal, organizational, and societal values and beliefs when making ethical decisions. In some cases, decisions are made that are beneficial to the organization and are communicated in such a way that the impact to the employees is lessened. The opposite is also true that organizational leaders make ethical decisions based on the best interest of the stakeholders, executive leadership, or decisions that serve their own self-interest. The two case studies present each type of ethical decision. The Malden Mills case shows where leadership frames the communication to promote or lessen the impact of the crisis. Malden Mills chose to base decisions on the interest of the employees, the company, and what would benefit the community overall. The Enron case study presents what happens, when the ethical decision making process is ignored and allowed to be unchecked. Enron's executives based their decisions on self-interest, which would benefit their own personal goals.

Crisis communication literature often suggests unethical communication practices to manage the external image of the company and the internal messages of crisis circumstances.

\section{DEFINING DOMINATE THEMES IN CRISIS MANAGEMENT}

Crises is defined as, "a specific, unexpected and non-routine event or series of events that create high levels of uncertainty and threaten or are perceived to threaten an organization's high priority goals" (Seeger, Sellnow, \& Ulmer, 1997, p.233). Crises will confront an organization in various types and degrees and will influence organizational operation and output. Potential damage that may ensue after crisis, an organization must be prepared to handle circumstances that threaten production targets.

Seeger et al. (1998) and Weick's (1988) definitions of organizational crisis provide a frame to examine dominant themes in crisis communication literature. An organizational crisis is a "specific, unexpected, and nonroutine event or series of events that create high levels of uncertainty and threaten or are perceived to threaten an organization's high-priority goals (Seeger et al., 1998, p. 233)." These unforeseen events threaten production targets of organizations. Crises provide challenges for the executive to fulfill contemporary and future objectives of the organization. Seeger et al. (1998) illustrate crises as "events that threaten the most fundamental goals of the organization...these events defy interpretations and impose severe demands on sensemaking (p. 305; Weick, 1988). These definitions explain how crises are circumstances that affect organizations when least suspected and confront efficient achievement of organizational goals.

When a crisis transpires, an organization is forced to enact strategies to confront possible damage within the organization. Dominant themes in the majority of crisis literature often reflect how individual organizations have managed crisis situations in the past. In these accounts, it is often suggested that organizations attempt to assign blame to individuals for implications of these unnatural events. Typically, if an organization is not assigning blame for the crisis, there are attempts to justify their reaction to events. The majority of crisis communication literature is concentrated on internal issue management strategies and creation of a stable external image of legitimacy after the crisis ensues.

Communication strategies from organizations that have responded to crises provide a retrospective and responsive account from affected organizations. Retrospective accounts combine organizational theory, public 
relations and mass communication study to account for events that are the results of crises. "Crisis communication is more reactive in the sense that it responds to trigger events after initial damage has occurred (Seeger et al. 1998, p. 265)." Examples of retrospective crisis accounts include communicative analyses of Enron (Seeger \& Ulmer, 2003), Texaco racism case (Coombs \& Schmidt, 2000), Nike (Knight \& Greenberg, 2002,) Malden Mills (Ulmer, 2001: Seeger \& Ulmer, 2002), Cole Hardwoods (Seeger \& Ulmer, 2002), and Philip Morris (Ulmer \& Sellnow, 1997). A majority of these crisis accounts describe unsuccessful approaches to handling organizational crises, as many of the companies were confronted with financial and reputation failure. Image or a firm's public relations are an important element for executives to contemplate when making decisions surrounding crisis. Benoit (1997) explains the value of a stable external image in an organization's public relations.

Image is essential to organizations (i.e., corporations, government bodies, non-profit groups) as well as individuals. Even if we are moving away from a notion of image as a single impression shared by an audience, image is still a central concept to the field of public relations. Firms may take preventative and restorative approaches to image problems. (Benoit, 1997, p. 177)

Benoit's theory of image restoration has served as a foundation for public relations studies because it provides strategies for public communication and positive perception of crisis (Coombs \& Schmidt, 2002). The external audience, including shareholders and other organizations, are concerned with their investments and interests in the organization that are confronted by crisis. When a stable image of the organization is articulated, shareholders are confident, markets remain stable and they are prepared for managerial shift after a crisis. To sustain confidence of their action and choices, organizations are encouraged to maintain their image as a legitimate and credible entity. Public relations are central to restoring the organization's accountability.

\section{CDM AND FRAMING IN BUSINESS ETHICS}

Street et al. (2001) propose an integrated model of ethical decision-making based on the issue contingent model (Jones, 1991) and the elaboration likelihood model (Petty \& Cacioppo, 1986). The Cognitive Elaboration Model of Ethical Decision Making allows for a better discussion of ethical decision-making as it pertains to the actual decision making process of the leadership within organizations. In this model, motivation and ability play a role in the level of cognitive expenditure measured as high or low expenditure. If the expenditure is low then a peripheral information processing occurs and a decision is based on non-ethical considerations. This leads to a low probability of ethical behavior during crisis management. If a high level of expenditure takes place then central information processing occurs to process the moral issue, at which time, judgment and intent is established and moral behavior is engaged. A more complete description of this model is presented by Street, et al. (2001) in the Organizational Behavior and Human Decision Processes Journal, 86(2), on page 265.

Makers of decisions use framing tools within public relations communiqué to stakeholders of organizations, membership of the organization, and society. Hallahan (1999) presents seven different models of framing or what we call framing tools that could be used to describe crisis communication in organizational crises. The seven models/tools include the framing of situations, attributes, choices, actions, issues, responsibility, and news. Through framing, public relations literature suggests that open communication is the most effective way to combat crises and preserve reputation of the organization. "A communication strategy should strive to achieve the fastest delivery of the most accurate information available (Penrose, 2000; p.158)." This public relations directive for managing external perception of the organization's actions during crisis encourages open and concise information to be a part of crisis response. This type of response will help an organization maintain an image of stability with management that has leadership capabilities to maintain fair and equitable practices. Organizations that create a crisis management plan are often prepared for unanticipated crisis (Penrose, 2000). These plans are most effective when "a policy of open communication within a company may be a more reliable predictor of crisis management success (Penrose, 2000p. 162)." Open communication during a crisis is encouraged to create an environment where the organizations values are considered a stable feature of organizations. When open communication is part of public relations, the organization will be able to preserve their reputation and create an atmosphere of confidence during and after a crisis. Open communication is critical because stakeholders expect to have a direct and honest account when crisis begins to effect the organization (Sturges, 1994). Open communication 
gives the perception of organizational control of the events that are disrupting the organizations function. "Compassion or concern for stakeholders is an overt or underlying element in research related to developing lists of crisis communication strategies and testing the effectiveness of crisis communication strategies" (Coombs, 1999; $p$. 127).

Framing of situations is the relationship between individuals and the situations they are found in during the course of a day. Framing of situations allows for the examination of the communication involved with the interactions occurring within the relationship (Hallahan, 1999). Within situational framing, crisis management occurs when decision makers use the available facts to decide whether the situation has escalated to be classified as a crisis.

Framing of attributes is a biased process whereby characteristics of objects and people are accentuated and others are ignored (Hallahan, 1999). This process allows some messages to be spun as having advantages or disadvantages to the organization and its stakeholders. Attributional framing in a crisis allows decision makers to accentuate some attributes of the crisis, as being positive to the organization and allowing other attributes to be pushed aside that could be detrimental to the message being sent to stakeholders and threaten image of the organization. Messages given by public relations divisions of businesses may use ambiguous messages as a strategy for framing attributes within crisis PR literature that is delivered to stakeholders, employees, and the public. Eisenberg (1984) discusses how strategic ambiguity should be central to an organization's messages. Strategic ambiguity encourages organizations to communicate with employees and shareholders with unclear intentions and values while delivering concise messages about the crisis circumstances to the public. This open but concise communication is essential to facilitating relationships and advancing innovative ideas within an organization. These messages should capture the important information but prioritize response strategies to articulate organizational values to the public.

Framing of risky choices proposes that individuals must not evaluate attributes but must make choices between two independent options even though some amount of risk is present (Hallahan, 1999). Using the cognitive decision-making model one option is to make the ethical decision while the other option is to make the non-ethical decision. Organizational behavior researchers have found that decision makers within organizations are willing to take greater risks to avoid losses rather than seek gains (Bailey \& Alexander, 1993; Bateman \& Zeithaml, 1989; Bazerman, 1984; Beach, 1997; Devine, 1990; Fagley \& Miller, 1987; Frisch, 1993; Hallahan, 1999; McDaniel \& Sistrunk, 1991; Pease, Bieser \& Tubbs, 1993). Within a crisis, decision makers may evaluate their choices among a continuum that evaluates the choices in terms of the gains and losses involved in each decision. Using the cognitive decision-making model, decision makers may make an unethical decision based upon gains or losses to the company rather than from a morally acceptable standpoint because the decision is ethical.

Framing of actions describes actions involved with persuading individuals to comply with a specific goal (Hallahan, 1999) settled upon by the decision makers of the organization. Decision makers use the framing of decisions to persuade members of organizations that the course of action being proposed is the best course of action to undertake for the organization in the specific crisis situation.

Framing of issues allows messages to be interpreted or examined (Hallahan, 1999) as it pertains to the messages being provided by the decision makers within the organization. Decision makers provide messages that are persuasive and intended to promote the well-being of the corporation. Organizational leadership must address the underlying issues as to why and how the crisis escalated, however, it is not necessarily true that the how's and why's are part of the message. In this respect, leadership frames the issue in terms that are beneficial to the corporation and the stakeholders involved with the corporation.

"Organizations attempt to influence members through oral messages from management and they communicate persuasively with parties in the 'external environment' through marketing, public relations, lobbying, testimony, image making, and issue advocacy; persuasion is inherent in the process of organizing" (Cheney, 1983; p. 144). When organizations enact consistent communication strategies, they emulate confidence around their response to crisis. When shareholders identify with organizational values through rhetoric, a personal connection 
with the organization will result. When individuals are confident with the organizational transition and response to crisis, they will be more confident with their response action.

Acceptance of credit or blame for the decisions rendered in a crisis situation account for the framing of responsibility or as suggested by Sillars (1982) attribution of an event to personal factors determines the extent to which an individual is held responsible (Hallahan, 1999). Organizational leaders must also explain to the person(s) responsible for the crisis and the cause of the crisis situation.

Leadership within organizations must project favorable messages to the public. Messages are framed in ways that protect the image of the organization. Leadership of the organization must attempt to garner positive responses from the public. This process of public relations is considered the framing of news. The public relations messages produced by organizations that are fed to the news media are spun to protect the business organization and the leadership of the organization through careful planning.

External communication is valuable in "developing a solid working relationship with the media before a crisis and sharing information with external publics are critical crisis management activities" (Penrose, 2000, p. 168). Consistent external communication that is parallel with the internal messages is important in maintaining confidence and long-range plans for the organization.

\section{MALDEN MILLS: ETHICAL DECISION MAKING THROUGH POSITIVE FRAMING}

Malden Mills, a textile company that was forced to rebuild after a fire destroyed their production facility, provides an example of successful organizational response to crisis. (Ulmer, 2001) Post-crisis discourse suggested that enactment, pre-crisis, and post crisis relations through transparent communication were reasons for successful resolution of crisis. Malden Mills strategies were successful because leadership of the organization played an important role in articulating clear and open communication with employees. This communication ensured identification of shareholders with the organization and connection to the organizations policies. Organizational values and crisis tactics were established with transparent communication and pre-crisis relationships, thereby promoting a sense of the corporate moral responsibility to the stakeholders of Malden Mills. The CEO of Malden Mills, Aaron Feuerstein, is described as possessing leadership qualities that are essential for maintaining organizational uniformity through crisis. Not only do these qualities promote a strong sense of leadership but also the promotion of a fair equitable value structure helped to strengthen the impact of the ethical decisions that were made. Feuerstein's pre and post-crisis communication sent a sensitive and compassionate message to members of the organization, as he provided fair treatment of the employees that resulted in organization members being confident with post-crisis events. By ensuring employees of benefits and pay with open communication of events during organizational reconstruction, he established internal confidence. Malden Mills strengthened internal and external confidence in crisis response action.

Feuerstein's positions on the values he held influenced his decisions and therefore the crisis response needed within the situation (Ulmer, 2001).He was able to use past philosophical tendencies, morals, and values to make decisions affecting the employees of Malden Mills positively and effectively. According to Weick (1979), past conduct by Feuerstein provided a repertoire of responses for the crisis (Ulmer, 2001). These responses through morally responsible decision-making allowed for his values to be placed ahead of corporate ideals. The decisions that he made were morally responsible in light of the crisis situation. His cognitive decision-making provided a successful crisis response.

Feuerstein's open communication with media and stakeholders of the organization was also imperative in establishing external confidence in the organization (Ulmer, 2001). According to Jeff Bowman, the media were an important stakeholder group for Malden Mills because as Bowman explained, "That the company was open, candid and accessible to the media and stakeholders" (Ulmer, 2001, p 601). Malden Mills transparency in public messages resulted in stakeholders resuming confidence with the organizations in their crisis response. Feuerstein provided a quick and accurate response to stakeholders soon after the crisis. This open communication demonstrated commitment and loyalty to renewal of the company. Open communication before, during, and after organizational 
crises assisted Malden Mills in creating a confident atmosphere where members within the organization and shareholders were able to identify with responses to crisis. The example of successful open communication can be used a model for other organizations to mimic when interacting with employees and shareholders as well as, with the media as a public relations framing tool.

The Malden Mills success story of crisis communication displays the value in consistent internal and external messages. Feuerstein, the CEO of Malden Mills, ensured that a consistent message was being delivered to stakeholders and individuals of the organization to generate organizational value (Ulmer, 2001). "Historically, Malden Mills worked to establish a strong sense that employees are valued. Relationships with workers are characterized by loyalty, reciprocity, and trust, and illustrate consistency in communication and value that cross situational boundaries (Ulmer, 2001, p 600)." This consistent message was important for the company to withstand the crisis that threatened the future of the organization. Organizations are encouraged to provide consistent internal and external messages to successfully prepare and handle crisis.

Feuerstein framed the crisis in multiple visions as the crisis affected the organization. In the beginning of the situation, Feuerstein framed the crisis in terms of actions, issues, responsibility and the news. Using the framing of actions, Feuerstein, promoted the ideal that a choice to be made and the best possible recourse that would positively affect the stakeholders would be the best choice to be made under the circumstances. The choice made was to maintain the ideals the company had maintained in the beginning to remain in business in Lawrence, rebuild the organization, and continue to pay the employees although they would not be working for at least thirty days (Seeger \& Ulmer, 2001). In responding to the idea of continuing to pay the employees Feuerstein said, "I consider the employees standing in front of me to be the most valuable asset that Malden Mills has. I don't consider them as some companies do as an expense that can be cut (Calo, 1996; Seeger \& Ulmer, 2001, p.605). Feuerstein accepted responsibility for his actions and promoted moral responsibility as important in assisting employees. Not only was this projected to the employees, but also to the community through the media outlets in the community.

Feuerstein consistently articulated organizational values and goals before and after crisis to ensure confidence in consumer response. Discourse about employee confidence and organizational renewal were prevalent in messages during the crisis. Seeger \& Ulmer (2002) analyzed the effectiveness of strategic ambiguity in postcrisis discourse, "Each time, he (Malden Mills CEO, Feuerstein) emphasized that employees were the company's most valuable assets" (p. 131). Feuerstein also used this communication strategy in messages articulate his commitment to the organization. The devotion to stakeholders and organizational renewal were important messages that reassured the public in addition to preserving confidence in the organization and to engender personal connection with the shareholders. These relationships were cultivated in pre-crisis communication and post crisis discourse with internal and external audiences to assure positive organizational change with focus of long-term organizational renewal.

Successful crisis resolution requires honest and ethical communication in times of crisis (Benoit, 1997). Credible messages about the potential cause or blame for crisis help the organization to create a connection to shareholders of the organization. An honest approach is essential during times of crisis. If communication during crisis events is not ethical, there could be detrimental reputation damage to the company if proper blame is not assigned for the causes of crisis. "Apart from the fact that this is morally the correct thing to do, attempting to deny true accusations allows an organization that falsely denies responsibility for offensive actions to risk substantial damaged credibility if the truth emerges" (Benoit, 1997, p.184). When an organization is honest with the events surrounding the crisis incidents, the internal and external audiences will respond by granting credible justification for crisis response.

\section{ENRON: POSITIVE (NEGATIVE) FRAMING THROUGH NON-ETHICAL DECISION-MAKING}

Enron at one point in its illustrious past had become an organization that was looked to as an industry leader and model of how corporations should do business, as well as, a case study in MBA programs of how to conduct business (Seeger \& Ulmer, 2003). This all occurred under the shroud of deceit, untruths, and cover-ups, which amounted to the quest for the almighty dollar or greed among corporate executives. Criticism levied about 
the management at Enron has come from commentators on the scandal and U. S. Senators. For example, commentator Carol Devine-Moline (2002) made the suggestion, "Enron was largely comprised of incredibly immoral, arrogant, and mercenary individuals that created a milieu of sleaziness and greed (Seeger \& Ulmer, 2003, p.69; "Lawmakers Blast," 2002)." United States Senator Byron Dorgan commentated on an internal Enron report that the company could be described as a "culture of corporate corruption... There are just so many tentacles to this story (Seeger \& Ulmer, 2003, p.69; "Lawmakers Blast," 2002)." Kenneth Lay was not immune to commentary as Senator Peter Fitzgerald described Lay as "an accomplished confidence man that had standards that were lower than that of a carnival barker (Seeger \& Ulmer, 2003, p.69; Fox, 2003, p.2).”

Enron's business leadership failed to deviate from the path they chose to traverse. Money was flowing for middle and upper management, whereby it was best not to know where the money was coming from and why it was being paid to them, and if the origin of the money was known it was best to act unknowledgeable. "Speculation occurred about the top executives at Enron that they either had culpability in the accounting issues or chose to ignore the issues because they did not want the gravy train of money, in the form of bonuses and stock options, to stop (Watkins, 2003, p.10)." Multi-million dollar deals were not overseen by top executives, which would protect the executive's interests of not knowing what was occurring (Seeger \& Ulmer, 2003).

Decisions were made cognitively to promote a sense of unknowledgeability, that is one could not be held accountable for what they did not know. However, it is the responsibility of an organization's governing body and/or representatives to understand and knowingly have knowledge of the workings of the organization. The debacle that occurred at Enron was not only about impending financial collapse, but also about the lack of moral responsibility the top executives had for the company's employees, the company, society, and themselves. Intentions were more based on the self-interest greed principle, rather than on an ethical principle. The greed principle can be described as the desire for individuals to want more and more based on a financial gain for self rather than for the well-being of others (emphasis ours).

"With the failure in responsibility at Enron came a breakdown in accountability. Kenneth Lay and Jeffrey Skilling have both publicly argued that they did not know about the wrongdoings at Enron and thus cannot be held culpable for the ethical and legal lapses (Seeger \& Ulmer, 2003, p.77)." Blame was given to the accounting firm (Arthur Andersen), consulting firms, and legal firms that represented Enron. The leadership at Enron had a moral and ethical responsibility to the employees, fellow executives, and other stakeholders to be informed about the financial woes of the corporation. Sherron Watkins, one of the whistle-blowers in the Enron case, sincerely believed that Enron would form a crisis management team to address issues concerning the accounting problems when they were exposed (Watkins, 2003).

Enron's public relations department was exceptionally adept at hiding the issues and problems facing the organization. Enron successfully used strategic ambiguity to spin messages to the public and its own employees. The endless output of good news and spin coming from the public relations machine at Enron became so overwhelming that executives and management could not or did not want to recognize that problems existed (Seeger \& Ulmer). Even in the face of a mounting financial crisis the public relations department would promote a positive view of the corporation to the employees and the public, whereby more common stock in the company would be purchased, theoretically pushing up the value of the stock but in fact the investments were mere investments into a "black hole".

The primary models of framing for the communication during the crisis at Enron could be situational, attributional, responsibility, and news/media coverage. Situational framing allowed the top executives to promote a sense of well-being to the employees and the public. Problems did not exist if they did not exist or in other words ignored. Framing in attributions allowed the issues pertaining to the crisis to be ignored. Ignorance of issues allowed for a biased viewpoint to proliferate the organization, thereby only allowing the characteristics of importance to be accentuated. Responsibility framing was used to provide an explanation to the causes of the crisis as being external forces causing the financial problems at Enron. Leadership perpetuated the ideal that the problems could be attributed to Arthur Andersen, the accountants, consulting firms and legal firms. Leadership did not accept responsibility for the poor judgments and actions performed by their management. The last framing model, 
news/media, was more manipulated by the public relations department at Enron. Enron's public relations people were able to promote a sense of prosperity at the corporation because everyone was making money.

Enron was and still is a catastrophe in corporate greed and lack of moral responsibility. Business ethics was a concept either forgotten or just not practiced. Kenneth Lay, CEO, was not the only culpable person in this scandal but the entire executive membership including middle management and lower management. Individuals must remember that ethics is an on-going process and choices are not necessarily going to be easy, but nonetheless choices must be made from a high cognitive decision making process.

\section{CONCLUSION}

Honest communication with employees and shareholders about organization values is a positive way to develop an ethical organization (Seeger \& Ulmer, 2003). In their analysis of the Enron corporate meltdown, ethical leadership principles were proposed. "(a) Communicating appropriate values to create a moral climate, (b) maintaining adequate communication to be informed of organizational operations, and (c) maintaining openness to signs of problems" (Seeger \& Ulmer, 2003, p. 63). The Enron meltdown took place because ethical decisions were not made and ethical communications were ignored as the crisis was developing. For organizational crises to be avoided, organizations are encouraged to approach their communication with responsibility and honesty. Organizations are encouraged to approach communication with these ethical guidelines to ensure they are given credibility and justification for their actions after a crisis.

"Ethical lapses at the top permeated throughout Enron even though Enron had a pristine code of ethics, code of conduct, and corporate governance procedures but were not being followed by top executives, middle management and lower management (Watkins, 2003, p.16)." Ethical leadership must come from the top (Watkins, 2003) and be allowed to permeate throughout the organization. According to Watkins (2003), "It is time for business leaders to do the right thing and recognize the moral responsibility part of our capitalist system and live up to that (p.14)." Enron is one example of crisis management run amok and the choices of moral responsibility and ethicality allowed to blow away in the wind, however not all corporations use the Enron model for corporate moral responsibility. Malden Mills used the opposite approach and allowed ethics and the communication of ethical principles to be the guideline to promote a positive moral view to the stakeholders involved with the crisis situation.

Ethical communication is a way of creating an internal and external relationship that can effectively negotiate crisis circumstances.

It is through discourse that individuals develop their own views of morality: through discourse that organizations develop and inculcate core values and ethical codes; and through discourse those incongruities within individual and organizational value-sets are managed and contradictions between the value sets of different persons are negotiated (Conrad, 1993, p. 2; Seeger \& Ulmer, 2003, p. 62).

Ethical communication is important when establishing a legitimate image within the organization. When a company creates an internal ethical bond, they will be granted credibility of their actions in response to organizational crisis. The successful crisis management in the Malden Mills fire crisis, Feuerstein was respected for his loyalty and reciprocity in response to crisis (Seeger \& Ulmer, 2002). When Feuerstein responded to the fire that destroyed the company's factory, he ensured worker confidence with discourse of stability and renewal. Feuerstein also provided assurance in discourse to shareholders by his loyalty and commitment to rebuild the company. His ethics during the time of crisis enables members of the organization to ease their tension about potential outcomes of crisis. Other organizations are encouraged to approach their internal and external communication with an ethical manner to ensure their post crisis actions are justified.

Proactive approaches to crisis management are recognized when executives of organizations commit to the stability of the company. In the Malden Mills crisis response, Feuerstein immediately committed to rebuilding the company (Seeger \& Ulmer, 2002). Despite the legal and insurance difficulties that are often results of crises, the discourse of recovery and organizational commitment enabled internal and external communication to be centered 
on positive organizational change. This response not only suggested the CEO's commitment to the organization, it established a proactive and positive response to change. By establishing identity within the organization and stakeholders creates an environment that is conducive for change and prepared for unexpected events. Organizations should follow Malden Mills example of optimistic crisis discourse that embodies the organization's commitment to employees and shareholders. Proactive approaches help organizations identify with internal and external audiences to ensure a credible response. On the other hand, Enron was neither a reactive nor a proactive response to a crisis situation but a cover-up of large-scale proportions. Response to the crisis was to continue to cover-up the true crisis, which was the occurring financial meltdown. Top executives were lying about the financial stability of the organization. Enron may have been the benchmark touted in leading MBA schools and for how entrepreneurial ventures should look in the hi-tech marketplace; however Enron is now the benchmark for corporate greed and collusionary practices.

\section{REFERENCES}

1. Bailey, J. J., \& Alexander, R. A. (1993). "Organizational social cues, framing and justice: Effects on management's ethical decisions". The International Journal of Organizational Analysis, 1, 133-160.

2. Bateman, T. S., \& Zeithaml, C. P. (1989). "The psychological context of strategic decisions: A model and convergent experimental findings". Strategic Management Research, 10, 59-74.

3. Bazerman, M. H. (1984). "The relevance of Kahneman and Tversky's concept of framing to organizational behavior". Journal of Management, 10, 333-343.

4. $\quad$ Beach, L. R. (1997). The psychology of decision-making: People in organizations. Thousand Oaks, CA: Sage.

5. Benoit, W.L. (1997). "Image repair discourse and crisis communication". Public Relations Review, 23, 177-190.

6. Calo, B. (Executive Producer). (1996, August 25). Labor of Love. New York: Dateline NBC.

7. Cheney, G., \& Christensen L.T. (2000). "Organizational identity, linkages between internal and external communication". The New Handbook of Organizational Communication. 231-269. Sage.

8. Cheney, G. (1983). "The rhetoric of identification and the study of organizational communication". Quarterly Journal of Speech, 69, 143-158.

9. $\quad$ Conrad, C. (1993). The ethical nexus. Norwood, NJ: Ablex.

10. Coombs, W.T., \& Schmidt, L. (2000). “An empirical analysis of Image Restoration: Texaco's racism crisis". Journal of Public Relations Research, 12, 163-175.

11. Coombs, W.T., (1999). "Information and compassion in crisis responses: A test of their effects". Journal of Public Relations Research, 11, 125-138.

12. $\quad$ DeGeorge, R. T. (1999). Business Ethics (5 ${ }^{\text {th }}$ Ed.). Upper Saddle River, NJ: Prentice Hall.

13. Devine, K. M. (1990). "The effects of information framing on decision-making behavior related to resource allocation”. Dissertation Abstracts International, 51(3-A), 919.

14. Fagley, N. S., \& Miller, P. M. (1987). "The effects of decision framing on choice and risky vs. certain options". Organizational Behavior \& Human Decision Processes, 39, 264-277.

15. Fox, L. (2003). Enron: The rise and fall. Hoboken, NJ: John Wiley.

16. Frisch, D. (1993). "Reasons for framing effects". Organizational Behavior \& Human Decision Processes, 54, 399-429.

17. Eisenberg, E.M. (1984). “Ambiguity as strategy in organizational communication”. Communication Monographs, 51, 227-242.

18. Hallahan, K. (1999). "Seven models of framing: Implications for public relations". Journal of Public Relations Research, 11, 205-242.

19. Harris, C. E. (2002). Applying Moral Theories $\left(4^{\text {th }}\right.$ Ed.). Belmont, CA: Wadsworth.

20. Jones, T. M. (1991). "Ethical decision making by individuals in organizations: An issue contingent model". Academy of Management Review, 16, 366-395.

21. Knight, F. \& Greenberg, J. (2002). "Promotionalism and subpolitics: Nike and its crisis management". Management Communication Quarterly, 15, 541-570.

22. "Lawmakers blast Enron's culture of corporate corruption: Enron CEO won't testify Monday before Senate panel". (2002). Retrieved form http://europe.cnn.com 
23. Lin, C. P. \& Ding, C. G. (2003). "Modeling information ethics: The joint moderating role of locus of control and job insecurity". Journal of Business Ethics, 48, 335-346.

24. McDaniel, W. C., \& Sistrunk, F. (1991). "Management dilemmas and decision: Impact of framing and anticipated responses". Journal of Conflict Resolution, 35, 21-42.

25. Morris, D. (2004). "Defining a moral problem in business ethics". Journal of Business Ethics, 49, $347-357$.

26. Pauchant, T., \& Mitroff, I. I. (1992). Transforming the Crisis Prone Organization. San Francisco: JosseyBass Publishers.

27. Pearson, C. M., \& Clair, J. A. (1998). "Reframing crisis management". Academy of Management Review, 22, 59-76.

28. Pease, P. W., Bieser, M., \& Tubbs, M. E. (1993). "Framing effects and choice shifts in group decision making”. Organizational Behavior \& Human Decision Processes, 56, 149-165.

29. Penrose, J.M. (2000). "The role of perception in crisis planning". Public Relations Review, 26, $155-177$.

30. Petty, R. E., \& Cacioppo, J. T. (1986). “The elaboration likelihood model of persuasion”. In L. Berkowitz (Ed.). Advances in experimental psychology (pp.123-205). New York: Academic Press.

31. Schwartz, P. (2000). "When good companies do bad things". Strategy and Leadership, 28, 4-11.

32. Seeger, M.W., \& Sellnow, T.L., \& Ulmer, R.R. (1997). "Communication, organization, and crisis”. In M. E. Roloff (Ed.), Communication Yearbook 21, 231-275. Thousand Oaks, CA: Sage.

33. Seeger, M.W., \& Ulmer, R.R. (2002). "A post-crisis discourse of renewal: The cases of Malden Mills and Cole Hardwoods". Journal of Applied Communication Research, 30, 126-142.

34. Seeger, M.W., \& Ulmer, R.R. (2003). "Explaining Enron: Communication and responsible leadership". Management Communication Quarterly, 17, 58-84.

35. Sillars, A. L. (1982). "Attribution and communication”. In M. E. Roloff \& C. R. Berger (Eds.), Social cognition and communication (pp. 73-106). Beverly Hills, CA: Sage.

36. Sturges, D.L. (1994). "Communicating through crisis, a strategy for organizational survival". Management Communication Quarterly 7, 297-316.

37. Simola, S. (2003). "Ethics of justice and care in corporate crisis management". Journal of Business Ethics, $46,351-361$.

38. Sims, R. R., \& Brinkman, J. (2002). "Leaders as role models: The case of John Gutfreund at Salamon Brothers". Journal of Business Ethics, 35, 327-339.

39. Street, M. D., Douglas, S.C., Geiger, S. W., \& Martinko, M. J. (2001). "The impact of cognitive expenditure on the ethical decision-making process: The cognitive elaboration model". Organizational Behavior and Human Decision Processes, 86, 256-277.

40. Street, M. D., Robertson, C., \& Geiger, S. W. (1997). "Ethical decision making: The effects of escalating commitment". Journal of Business Ethics, 16, 1153-1161.

41. Ulmer, R.R. (2001). "Effective crisis management through established stakeholder relations at Malden Mills as a case study". Management Communication Quarterly, 14, 590-615.

42. Ulmer, R.R. \& Sellnow, T.L. (1997). "Strategic ambiguity and the ethic of significance in the tobacco industry's crisis communication". Communication Studies, 48, 215-233.

43. Velasquez, M. G. (1998). Business Ethics ( $4^{\text {th }}$ Ed.). Upper Saddle River, NJ: Prentice Hall.

44. Watkins, S. S. (2003). "Ethical conflicts at Enron: Moral responsibility in corporate capitalism". California Management Review, 45, 6-19.

45. Weick, K. E. (1988). "Enacted sensemaking in crisis situations". Journal of Management Studies, 25, 305317 .

46. Weick, K. E. (1979). The social psychology of organizing (2 ${ }^{\text {nd }}$ ed.). New York: McGraw-Hill. 
Notes 